\title{
Aminoguanidine, an Inhibitor of Inducible Nitric Oxide Synthase, Ameliorates Experimental Autoimmune Encephalomyelitis in SJL Mice
}

Anne H. Cross, * Thomas P. Misko, ${ }^{\star}$ Robin F. Lin, ${ }^{*}$ William F. Hickey, John L. Trotter, * and Ronald G. Tilton

Departments of * Neurology and ${ }^{\S}$ Pathology, Washington University School of Medicine, Saint Louis, Missouri 63110 and ${ }^{\ddagger}$ Molecular Pharmacology, Searle Inflammation Disease Research Group, Monsanto Company, Saint Louis, Missouri 63167

\begin{abstract}
Previous work from our laboratory localized nitric oxide to the affected spinal cords of mice with experimental autoimmune encephalomyelitis, a prime model for the human disease multiple sclerosis. The present study shows that activated lymphocytes sensitized to the central nervous system encephalitogen, myelin basic protein, can induce nitric oxide production by a murine macrophage cell line. Induction was inhibited by aminoguanidine, a preferential inhibitor of the inducible nitric oxide synthase isoform, and by $\boldsymbol{N}^{\mathbf{G}}$-monomethyl-L-arginine. Aminoguanidine, when administered to mice sensitized to develop experimental autoimmune encephalomyelitis, inhibited disease expression in a dose-related manner. At $\mathbf{4 0 0}$ mg aminoguanidine / $\mathrm{kg}$ per day, disease onset was delayed and the mean maximum clinical score was $0.9 \pm 1.2$ in aminoguanidine versus $3.9 \pm 0.9$ in placebo-treated mice. Histologic scoring of the spinal cords for inflammation, demyelination, and axonal necrosis revealed significantly less pathology in the aminoguanidinetreated group. The present study implicates excessive nitric oxide production in the pathogenesis of murine inflammatory central nervous system demyelination, and perhaps in the human disease multiple sclerosis. (J. Clin. Invest. 1994. 93:2684-2690.) Key words: allergic encephalomyelitis • nitric oxide - multiple sclerosis $\cdot$ demyelinating diseases $\bullet$ autoimmune diseases
\end{abstract}

\section{Introduction}

Despite numerous advances in the past decade, the cause and pathogenesis of the inflammatory central nervous system (CNS) ${ }^{1}$ demyelinating disorder, multiple sclerosis (MS), remain unknown. Experimental autoimmune encephalomyelitis (EAE), an inflammatory CNS demyelinating disorder which serves as the prime animal model for MS, can be induced in a number of species by immunization with myelin components or injection of autoimmune T lymphocytes (1-3).

Address reprint requests to Dr. Anne H. Cross, Department of Neurology, Washington University School of Medicine, Box 8111, 660 South Euclid Avenue, St. Louis, MO 63110. Dr. Hickey's present address is Department of Pathology, Dartmouth University, Lebanon, NH. 1994.

Received for publication 28 July 1993 and in revised form 5 January

1. Abbreviations used in this paper: CNS, central nervous system; EAE, experimental autoimmune encephalomyelitis; iNOS, inducible nitric oxide synthase; LNC, lymph node cell; L-NMA, $\mathrm{N}^{\mathrm{G}}$-monomethyl-L-arginine; MBP, myelin basic protein; MS, multiple sclerosis.

J. Clin. Invest.

(c) The American Society for Clinical Investigation, Inc. 0021-9738/94/06/2684/07 \$2.00

Volume 93, June 1994, 2684-2690
Recent evidence from this laboratory (4) and others $(5,6)$ have documented the presence of nitric oxide (NO) or its products in the affected tissues or cells of mice and rats with EAE. $\mathrm{NO}$, a gaseous free radical, has been implicated in the pathogenesis of a variety of inflammatory/immunologically mediated disorders (7). Although it functions as a cellular messenger, $\mathrm{NO}$ is thought to play a role in pathologic processes due to its cytotoxicity at high concentrations $(8,9)$. NO is produced in large quantity by activated macrophages, astrocytes, and other cell types via an inducible isoform of nitric oxide synthase (iNOS) (10-14). Studies from this laboratory using electron paramagnetic resonance spectroscopy demonstrated nitrosyliron complexes (indicative of NO presence) in spinal cords of mice with EAE, with concurrent decrements in iron-sulfur proteins important to the function of a number of cellular enzymes (4).

Aminoguanidine, a nucleophilic hydrazine compound, has recently been shown to be a selective inhibitor of iNOS (15, 16). Because our previous work indicated elevated NO levels in EAE-affected CNS consistent with its production by iNOS together with destruction of iron-sulfur proteins, a potentially toxic effect, our study was undertaken to investigate effects of aminoguanidine upon the course and pathology of adoptively transferred EAE in the SJL mouse strain. The results of controlled, blinded experiments support a role for NO in the pathogenesis of this disorder.

\section{Methods}

Mice. Pathogen-free SJL females aged 6-12 wk were obtained from Jackson Laboratories (Bar Harbor, ME) and were housed and maintained in microisolator cages in accordance with guidelines set forth by the Washington University Committee for the Humane Care of Laboratory Animals and the NIH regarding laboratory animal welfare.

Aminoguanidine treatment of mice given lipopolysaccharide to induce nitric oxide synthase. 10 female SJL mice were used in this experiment. Two mice each were treated with $100 \mathrm{mg}$ aminoguanidine $/ \mathrm{kg}$ per day subcutaneously (s.c.), $200 \mathrm{mg}$ aminoguanidine $/ \mathrm{kg}$ per day s.c., $400 \mathrm{mg}$ aminoguanidine $/ \mathrm{kg}$ per day s.c., $400 \mathrm{mg}$ aminoguanidine $/ \mathrm{kg}$ per day intraperitoneally (i.p.) or saline s.c. for $12 \mathrm{~h}$ before and after intravenous injection of $20 \mu \mathrm{g}$ lipopolysaccharide (Escherichia coli serotype 0111:B4; Sigma Chemical Co., St. Louis, MO). Serum samples from each animal were obtained at 0-, 3-, 6-, and 10-h time points by retroorbital venous puncture of methoxyfluorane-anesthetized mice. Serum nitrate and nitrite levels were determined as described below.

Induction of EAE by adoptive transfer. The method of EAE induction was similar to that published previously (17). The encephalitogen myelin basic protein (MBP) was prepared from guinea pig spinal cords (Rockland, Inc., Gilbertsville, PA) according to a published method (18). SJL mice were immunized subcutaneously in four sites over the flanks with $400 \mu \mathrm{g}$ MBP emulsified with $60 \mu \mathrm{g}$ Mycobacterium tuberculosis, $\mathrm{H}_{37} \mathrm{RA}$ (Difco Laboratories, Detroit, MI). $10 \mathrm{~d}$ later, draining axial, brachial, and inguinal lymph nodes were removed and a singlecell suspension was prepared by pressing nodes through sterile 50 -mesh stainless steel. Lymph node cell (LNC) number and viability were as- 
sessed by trypan blue exclusion. Cells were plated at $4 \times 10^{6} / \mathrm{ml}$ in media consisting of RPMI 1640 (Sigma Chemical Co.) supplemented with nonessential amino acids, sodium pyruvate, $10^{-5} \mathrm{M} \beta$-mercaptoethanol (Sigma Chemical Co.), penicillin G (100 U/ml, Sigma Chemical Co.), glutamine ( $2 \mathrm{mM}$, Sigma Chemical Co.), and Hepes buffer to which was added $50 \mu \mathrm{g} \mathrm{MBP} / \mathrm{ml}$ and $10 \% \mathrm{FBS}$ (GIBCO, Grand Island, NY). After $3 \mathrm{~d}$ at $37^{\circ} \mathrm{C}, 7 \% \mathrm{CO}_{2}$, cells were washed twice and injected intravenously together with $50 \mathrm{ng}$ pertussis toxin (List Biologic Laboratories, Campbell, CA ) into 6-8-wk-old syngeneic recipient mice.

Clinical grading of EAE. Mice were evaluated daily and graded by a blinded investigator according to the following scale: grade $1=\operatorname{limp}$ tail; grade 2 = hind limb weakness sufficient to impair righting; grade 3 $=$ one limb plegic; grade $4=$ two limbs plegic; grade $5=3$ or 4 limbs plegic or the animal was moribund (17). Relapses were defined as worsening by at least one grade lasting $\geq 48 \mathrm{~h}$.

Aminoguanidine treatment of mice induced to develop EAE. Mice were treated from the day of cell transfer with the iNOS inhibitor, aminoguanidine hemisulfate (Sigma Chemical Co.; $\mathrm{LD}_{\mathbf{5 0}} \sim 1,600 \mathrm{mg}$ / $\mathrm{kg}$ per day, A. H. Cross and R. G. Tilton, unpublished studies). Coded samples of aminoguanidine dissolved in PBS or placebo (PBS) were administered by a blinded investigator. Three dosing schedules were used: three times per day (total dose $400 \mathrm{mg} / \mathrm{kg}$ per day; $100 \mathrm{mg} / \mathrm{kg}$ at 9:00 a.m., $100 \mathrm{mg} / \mathrm{kg}$ at 1:00 p.m. and $200 \mathrm{mg} / \mathrm{kg}$ at 5:00 p.m., i.p.); twice daily $(200 \mathrm{mg} / \mathrm{kg}$ per day; $100 \mathrm{mg} / \mathrm{kg}$ at 9:00 a.m. and 100 $\mathrm{mg} / \mathrm{kg}$ at 5:00 p.m., s.c.); or once a day $(100 \mathrm{mg} / \mathrm{kg}$ per day, at 9:00 a.m., s.c.).

Spectrofluorimetric determination of nitrite and nitrate. The RAW 264.7 murine macrophage line (American Type Tissue Collection, Rockville, MD) was maintained in DME supplemented with glutamine, and 10\% FBS. The RAW 264.7 cells were placed in MEM containing Earle's salts (without phenol red; GIBCO) for induction experiments. The ability of MBP-sensitized LNC or their supernatant fluids to induce NOS activity in the murine macrophage cell line RAW 264.7 was determined by the measurement of nitrite levels in the resulting conditioned media using modifications of a published method (19). Antibodies to murine IFN- $\gamma$ (monoclonal hamster), TNF $\alpha$ (polyclonal rabbit antiserum), and IL- $1 \beta$ (polyclonal rabbit anti-human IL-1 $\beta$ which cross-reacts with mouse) were obtained from Genzyme Corp. (Cambridge, MA). 2,3-Diaminonaphthalene was reacted with nitrite under acidic conditions to form $\left[{ }^{1} \mathrm{H}\right]$ naphthotriazole, a fluorescent product. Nitrite standards ( $>98 \%$ pure, Sigma Chemical Co.) were made fresh for each determination. Formation of 2,3-diaminonaphthotriazole was measured using a fluorescent plate reader (Pandex; IDEXX Laboratories, Inc., Westbrook, ME) with excitation at $365 \mathrm{~nm}$ and emission read at $450 \mathrm{~nm}$. The assay is sensitive to nitrite concentrations as low as $10 \mathrm{nM}(20) .2 \mathrm{mM}$ aminoguanidine or $2 \mathrm{mM} N^{\mathrm{G}}$. monomethyl-L-arginine (L-NMA; Sigma Chemical Co.) was added to some reaction mixtures to inhibit murine NOS induced by the activated MBP-sensitized LNC. These concentrations were used because the MEM itself contains $500 \mu \mathrm{M}$ arginine. Nitrate reductase was added to serum assays to measure nitrate in addition to nitrite (20).

Effect of aminoguanidine on EAE-inducing cells in vitro. Two types of experiments were used to determine the effect of aminoguanidine upon EAE-inducing cells. For adoptive transfer, during the 3-d antigen stimulation period, one-half of the cells to be used for transfer were cultured in $100 \mu \mathrm{M}$ aminoguanidine and the other half were cultured without aminoguanidine. The four recipients (two from each culture) were observed daily for development of clinical EAE.

Proliferation assays were the second method used to determine the effect of aminoguanidine upon LNC. In the presence or absence of 100 $\mu \mathrm{M}$ aminoguanidine, $\mathrm{LNC}$ were plated in quadruplicate in 96-well flatbottomed microtiter plates at $8 \times 10^{5} /$ well in EAE medium supplemented with $5 \%$ FCS. MBP ( $50 \mu \mathrm{g} / \mathrm{ml})$, concanavalin A $(4 \mu \mathrm{g} / \mathrm{ml}$, Sigma Chemical Co.), or medium alone was added to a final vol of 200 $\mu \mathrm{l} /$ well. During the final $18 \mathrm{~h}$ of culture, $1 \mu \mathrm{Ci} /$ well [methyl- ${ }^{3} \mathrm{H}$ ]thymidine, $25 \mathrm{Ci} / \mathrm{mmol}$ (Amersham Corp., Arlington Heights, IL) was added to each well after which the plates were harvested using a semiau- tomated multichannel harvesting device (Skatron, Inc., Sterling, VA) onto glass fiber filters and counts per minute were determined by liquid scintillation using standard techniques. The stimulation index (SI) was calculated as follows: $\mathrm{SI}=$ mean $\mathrm{cpm}$ of cells cultured with antigen or mitogen/mean cpm of cells cultured in medium alone.

EAE histology in aminoguanidine-and placebo-treated mice. 15 aminoguanidine- and 14 placebo-treated mice were anesthetized by methoxyfluorane inhalation and perfused through the left cardiac ventricle with $40 \mathrm{ml}$ of cold $2.5 \%$ buffered glutaraldehyde (Electron Microscopy Sciences, Fort Washington, PA). The brain and spinal cord were removed and thin slices at all levels of CNS including spinal cord (cervical, midthoracic, upper lumbar, $\mathrm{L}_{6}, \mathrm{~L}_{7}$, and sacral) and sacral roots were postfixed in cold $1 \%$ osmium tetroxide (Electron Microscopy Sciences) for $60 \mathrm{~min}$, after which sections were dehydrated through graded ethanols, cleared in propylene oxide, and embedded in EMBED 812 (Electron Microscopy Sciences). $1-\mu \mathrm{m}$ sections placed on slides were stained with toluidine blue and scored blindly using a published scoring system (21). Multiple sections from the $\mathrm{L}_{5}, \mathrm{~L}_{6}$, and sacral spinal cord were scored from 0 to 5 for inflammation, demyelination, remyelination, and axonal necrosis.

Histology of CNS and systemic organs in normal mice treated with aminoguanidine. Two normal SJL female mice treated 3 wk with 400 $\mathrm{mg}$ aminoguanidine/ $\mathrm{kg}$ per day i.p. were perfused, fixed, and sectioned as described above but including systemic organs (lungs, heart, liver, spleen, kidneys, and pancreas) as well as the entire neuraxis (cerebrum, cerebellum, brainstem, cervical, thoracic, and lumbar and sacral spinal cord). A normal, untreated, age-matched SJL female was perfused at the same time as a reference. Multiple sections from each organ or CNS region were examined in blinded fashion.

Serial transfer experiments. Five control, placebo-treated mice with EAE and seven aminoguanidine-treated mice served as donors for the serial transfer of EAE (22). Donor spleens were removed aseptically, and single-cell suspensions were prepared by pressing spleens through sterile mesh. Red blood cells were lysed with ammonium chloride. Spleen cells were cultured $3 \mathrm{~d}$ with $50 \mu \mathrm{g} \mathrm{MBP} / \mathrm{ml}$. After in vitro stimulation, spleen cells were injected $\left(5-9 \times 10^{7}\right.$ cells per recipient) into naive syngeneic recipients.

Statistical analyses. Group differences in the clinical scores were analyzed by ANOVA and by the nonparametric Van der Waerden test, which makes no assumptions regarding data distribution. Time to clinical onset was analyzed using Kaplan-Meier survival tests. Inflammation, demyelination, necrosis, and remyelination scores were analyzed for differences between groups using a split-plot factorial. For analysis of pathology, three factors were tested: difference between treatment groups, differences between areas, and the interaction between the two. Results were considered significantly different if $P<0.05$.

\section{Results}

Effect of aminoguanidine on serum nitrite and nitrate levels of LPS-treated SJL mice

To determine the effect of aminoguanidine treatment on NO levels induced by LPS, serial blood samples obtained from mice treated with placebo or aminoguanidine in the same dosing schedules used in the EAE studies were analyzed for nitrite and nitrate. Before LPS injection, the baseline serum nitrite for all mice was $39.7 \pm 11.2 \mu \mathrm{M}$. By $10 \mathrm{~h}$ after injection, serum nitrite and nitrate had risen to $263 \pm 26 \mu \mathrm{M}$ in the placebotreated mice and were $225 \pm 118 \mu \mathrm{M}$ in mice treated with 100 $\mathrm{mg}$ aminoguanidine/ $\mathrm{kg}$ per day s.c., $92.5 \pm 24 \mu \mathrm{M}$ in the 200 $\mathrm{mg} / \mathrm{kg}$ per day s.c. group, $91 \pm 19 \mu \mathrm{M}$ in the $400 \mathrm{mg} / \mathrm{kg}$ per day s.c. group, and $118 \pm 42 \mu \mathrm{M}$ in the $400 \mathrm{mg} / \mathrm{kg}$ per day i.p. group.

\section{Effects of aminoguanidine upon EAE}

Clinical data. A total of 41 mice ( 21 aminoguanidine- and 20 placebo-treated) were used in these studies. The treated and 


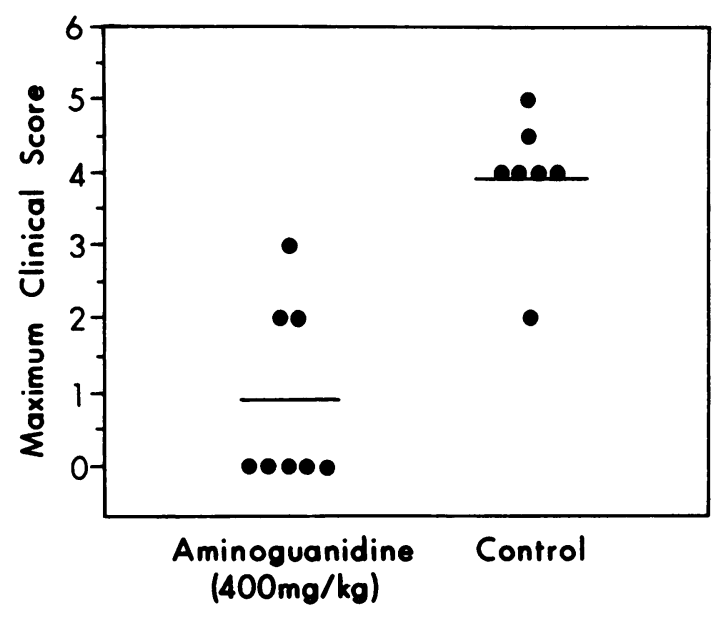

Figure 1. Maximum clinical scores of mice treated with high dose aminoguanidine or placebo. Plot of the maximum clinical score displayed by each of the mice treated with $400 \mathrm{mg}$ aminoguanidine $/ \mathrm{kg}$ per day (left) or with placebo (right). The mean score is indicated by a bar.

control groups were compared with regard to maximal clinical score and time to clinical onset of EAE. No differences were noted between placebo groups of different experiments $(P$ $=0.49$ ). The results showed that the highest dose of aminoguanidine used $(400 \mathrm{mg} / \mathrm{kg}$ per day i.p.) completely suppressed clinical expression of EAE in five out of eight treated mice (Fig. 1). Two of these mice were followed for $2 \mathrm{wk}$ after discontinuation of aminoguanidine and did not become ill. However, the transfer of spleen cells from these two mice into individual naive recipients resulted in typical EAE in both recipients. The three mice treated with $400 \mathrm{mg} / \mathrm{kg}$ aminoguanidine that developed EAE displayed less severe disease than the controls (Fig. 1). The difference in maximum clinical score between aminoguanidine and placebo groups were significant with $P=0.0001$ using either ANOVA or Van der Waerden Scores.

At $200 \mathrm{mg} / \mathrm{kg}$ per day, only one of four mice developed clinical EAE. At this dose, maximal clinical scores were reduced in the aminoguanidine-treated groups compared with controls, with $P=0.059$ by ANOVA and $P=0.032$ by Van der Waerden scores. Differences in maximum clinical scores for the $100 \mathrm{mg} / \mathrm{kg}$ dose were not significantly different between

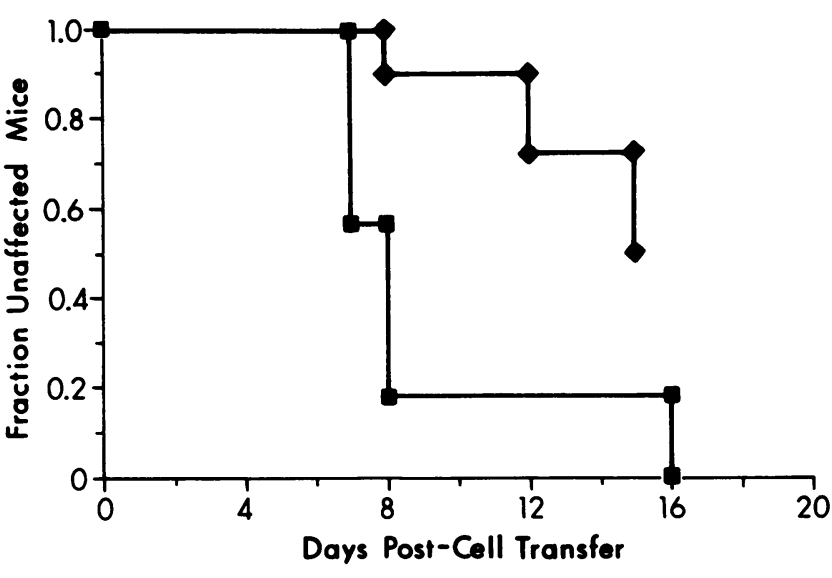

Figure 2. Time to clinical onset of EAE for aminguanidine- and placebo-treated mice using Kaplan-Meier survival analysis. $400 \mathrm{mg} / \mathrm{kg}$ per day aminoguanidine-treated mice $(\diamond)$; placebo-treated mice $(\boldsymbol{\bullet})$. Note that the fraction of aminoguanidine recipients that are not ill is always greater than the healthy fraction of the placebo group. Because the fraction of unaffected aminoguanidine-treated mice was reduced each time a healthy member showing no signs was sacrificed for pathology, had the group been allowed to live longer the difference between aminoguanidine- and placebo-treated would have been greater and the true curve for the aminoguanidine-treated group would be shifted upward and to the right.

treated and placebo groups $(P=0.15$ by ANOVA; $P=0.13$ by Van der Waerden) (Table I).

Time to EAE onset was significantly delayed at the 400 $\mathrm{mg} / \mathrm{kg}$ per day dose $(P=0.0087)$, even though healthy aminoguanidine recipients were considered "sick" at the time of sacrifice for histology, for calculation purposes (Fig. 2). Time to EAE onset was not significantly different for the 100 and 200 $\mathrm{mg} / \mathrm{kg}$ per day dose groups. In aminoguanidine-treated mice, no weight loss occurred and the internal organs appeared grossly normal. When administered subcutaneously, a bluish skin discoloration was sometimes observed at the site of injection.

\section{Effects of aminoguanidine upon normal SJL mice}

Blinded examination of multiple $1-\mu \mathrm{M}$ sections of body organs and the entire CNS of two normal SJL mice treated for $21 \mathrm{~d}$ with $400 \mathrm{mg}$ aminoguanidine/ $\mathrm{kg}$ per day i.p. revealed no pathologic abnormalities. In addition, no clinical abnormali-

Table I. NOS Inhibition In Vivo: Effect Upon EAE

\begin{tabular}{|c|c|c|c|c|}
\hline Treatment group & $n$ & Mean maximum score (range) $\pm S D$ & Median score & $\begin{array}{c}P \\
\text { value }\end{array}$ \\
\hline Aminoguanidine, $400 \mathrm{mg} / \mathrm{kg}$ per day & 8 & $0.88 \pm 1.25(0-3)$ & 0 & $0.0001^{*, \neq}$ \\
\hline Placebo & 7 & $3.93 \pm 0.93(2-5)$ & 4 & $0.06^{*}$ \\
\hline Aminoguanidine, $200 \mathrm{mg} / \mathrm{kg}$ per day & 4 & $0.63 \pm 1.23(0-2.5)$ & 0 & $0.03^{\ddagger}$ \\
\hline Placebo & 4 & $3.13 \pm 1.75(0.5-4)$ & 4 & $0.15^{*}$ \\
\hline $\begin{array}{l}\text { Aminoguanidine, } 100 \mathrm{mg} / \mathrm{kg} \text { per day } \\
\text { Placebo }\end{array}$ & $\begin{array}{l}9 \\
9\end{array}$ & $\begin{array}{l}2.28 \pm 1.33(0-4) \\
3.22 \pm 1.33(1-5)\end{array}$ & $\begin{array}{l}2.5 \\
3 .\end{array}$ & $0.13^{\ddagger}$ \\
\hline
\end{tabular}

* By ANOVA. ${ }^{\ddagger}$ By Van der Waerden nonparametric testing. 
ties or weight loss were observed in five mice treated longer than 3 wk with aminoguanidine at this dose.

\section{Effects of aminoguanidine upon EAE histology}

CNS tissues from at least three spinal cord levels (including lumbar and sacral) were examined histologically and scored blindly in each perfused mouse. For the high dose aminoguanidine group, there was a marked and significant reduction in inflammation $(P<0.02)$, demyelination $(P<0.02)$, and necrosis ( $P<0.05$; see Table II, and Figs. 3, $A$ and $B)$. Virtually no necrosis was observed in sections from aminoguanidinetreated mice (Fig. $3 \mathrm{~B}$ ). At the lower doses, no differences were observed between aminoguanidine- and control-treated CNS tissues in inflammation or demyelination. A trend for aminoguanidine-treated mice to display less axonal destruction emerged, but did not achieve statistical significance.

Induction of NOS in RAW 264.7 cells by MBP-sensitized $L N C$. Inhibition with aminoguanidine and anti-IFN- $\gamma$

LNC from MBP-immunized mice or their supernates after activation in vitro $48-72 \mathrm{~h}$ with $50 \mu \mathrm{g} \mathrm{MBP} / \mathrm{ml}$ induced NOS activity in murine macrophages (RAW 264.7) as determined by nitrite production (Fig. 4). Nitrite production by RAW cells was inhibited with 2 or $10 \mathrm{mM}$ aminoguanidine or 2 or $10 \mathrm{mM}$ L-NMA, indicating it to be due to NOS induction. Relatively high concentrations of these two NOS inhibitors were used because of the high L-arginine content of Earles's MEM and RPMI 1640 in which the RAW cell induction experiments took place. Supernatant fluids from activated MBP-sensitized LNC contained little nitrite $(\leq 1 \mu \mathrm{M})$, as did the supernates of unstimulated RAW cells (Fig. 4), RAW cells cultured with naive, unimmunized LNC $(<1 \mu \mathrm{M})$, or RAW cells to which $50 \mu \mathrm{g} \mathrm{MBP} / \mathrm{ml}$ had been added $(<1 \mu \mathrm{M})$. In two experiments, monoclonal antibody to murine IFN- $\gamma(20 \mu \mathrm{g} / \mathrm{ml})$ completely abrogated induction of iNOS in RAW cells by MBP-reactive cells, as measured by nitrite levels. Anti-TNF- $\alpha$ or anti-IL-1 $\beta$ (both used at 1:100 dilution) had no effect upon iNOS induction in RAW cells by MBP-reactive cells.

\section{Effect of aminoguanidine in vitro}

The two recipients of cells cultured in the presence of $100 \mu \mathrm{M}$ aminoguanidine developed typical EAE with the same latency ( $7 \mathrm{~d}$ ) and severity (maximum clinical grades of 5 and 2) as the recipients of cells not cultured in the presence of aminoguanidine.

Specific proliferation to antigen ( $50 \mu \mathrm{g} \mathrm{MBP} / \mathrm{ml}$ ) or mitogen ( $4 \mu \mathrm{g}$ concanavalin $\mathrm{A} / \mathrm{ml})$ in the presence and absence of $100 \mu \mathrm{M}$ aminoguanidine was determined for MBP-sensitized LNC. In three separate experiments aminoguanidine did not suppress proliferation to MBP. Background counts were similar in the presence or absence of aminoguanidine. In two of three experiments there was no suppression of proliferation to mitogen, even when aminoguanidine was added at $200 \mu \mathrm{M}$. In one of the three experiments suppression of the response to mitogen was observed in the presence of $100 \mu \mathrm{M}$ aminoguanidine (SI 51 without vs. SI 27 with aminoguanidine).

\section{Serial transfer experiments}

To further assess whether the effect of aminoguanidine treatment in vivo might be secondary to a deleterious effect upon EAE inducer cells, serial transfer of splenocytes from seven aminoguanidine-treated mice into eight naive recipients was performed in parallel with serial transfers of spleen cells from five controls into five recipients. Serial transfer produced typical EAE in all but one of the recipients in each group. The mean maximum clinical score for the recipients of SC from

Table II. Histologic Analysis of Spinal Cords of Aminoguanidine-Treated and Control Mice

\begin{tabular}{|c|c|c|c|c|c|c|c|c|c|c|c|}
\hline \multicolumn{6}{|c|}{ Aminoguanidine at $400 \mathrm{mg} / \mathrm{kg}$ per day } & \multicolumn{6}{|c|}{ Control } \\
\hline Animal & Area & Inflam & Demylen & Necrosis & Remylen & Animal & Area & Inflam & Demylen & Necrosis & Remylen \\
\hline A297 & $\mathrm{L}_{5}$ & 0 & 0 & 0 & 0 & A295 & $\mathrm{L}_{5}$ & 2 & 0 & 0 & 0 \\
\hline A297 & $\mathrm{L}_{6}$ & 0 & 0 & 0 & 0 & A295 & $\mathrm{L}_{6}$ & 2 & 4 & 0 & 1 \\
\hline A297 & Sacral & 0 & 0 & 0 & 0 & A295 & Sacral & 3 & 2 & 0 & 0 \\
\hline A300 & $\mathrm{L}_{5}$ & 0 & 0 & 0 & 0 & A298 & $\mathrm{L}_{5}$ & 3 & 1 & 0 & 0 \\
\hline A 300 & $\mathrm{~L}_{6}$ & 0 & 0 & 0 & 0 & A298 & $\mathrm{L}_{6}$ & 4 & 1 & 0 & 0 \\
\hline A300 & Sacral & 1 & 0 & 0 & 0 & A298 & Sacral & 3 & 2 & 0 & 1 \\
\hline A299 & Upper L & 0 & 0 & 0 & 0 & A296 & Upper L & 0 & 0 & 0 & 1.5 \\
\hline A299 & $\mathrm{L}_{5}$ & 0 & 0 & 0 & 0 & A296 & $\mathrm{L}_{5}$ & 0 & 0 & 0 & 0 \\
\hline A299 & Sacral & 0 & 0 & 0 & 0 & A296 & $\mathrm{L}_{6}$ & 1 & 2 & 2 & 1 \\
\hline A301 & Upper L & 0 & 0 & 0 & 0 & A296 & Sacral & 1 & 2 & 1 & 2 \\
\hline A301 & $\mathbf{L}_{5}$ & 0 & 0 & 0 & 0 & A329 & $\mathrm{L}_{5}$ & 2 & 2 & 0 & 0 \\
\hline A301 & Sacral & 0 & 0 & 0 & 0 & A329 & $\mathrm{L}_{6}$ & 3 & 2 & 1 & 0 \\
\hline A328 & $\mathrm{L}_{5}$ & 0 & 0 & 0 & 0 & A 329 & Sacral & 3 & 2 & 1 & 0 \\
\hline A328 & $\mathbf{L}_{6}$ & 0 & 0 & 0 & 0 & A322 & $\mathrm{L}_{5}$ & 4 & 4 & 1 & 1 \\
\hline A328 & Sacral & 0 & 0 & 0 & 0 & A322 & $\mathrm{L}_{6}$ & 4 & 4 & 1 & 1 \\
\hline A323 & $\mathrm{L}_{5}$ & 2 & 1 & 0 & 0 & A 322 & Sacral & 4 & 5 & 1 & 1 \\
\hline A323 & $\mathrm{L}_{6}$ & 2 & 1 & 0 & 0 & A324 & $\mathrm{L}_{5}$ & 3 & 4 & 2 & 2 \\
\hline A323 & Sacral & 4 & 4 & 0 & 0 & A324 & $\mathrm{L}_{6}$ & 3 & 4 & 3 & 1 \\
\hline A325 & $\mathrm{L}_{5}$ & 3 & 2 & 0 & 0 & A324 & Sacral & 3 & 5 & 3 & 1 \\
\hline A325 & $\mathrm{L}_{6}$ & 2 & 2 & 0 & 0 & & & & & & \\
\hline A325 & Sacral & 4 & 3.5 & 1 & 1 & & & & & & \\
\hline
\end{tabular}



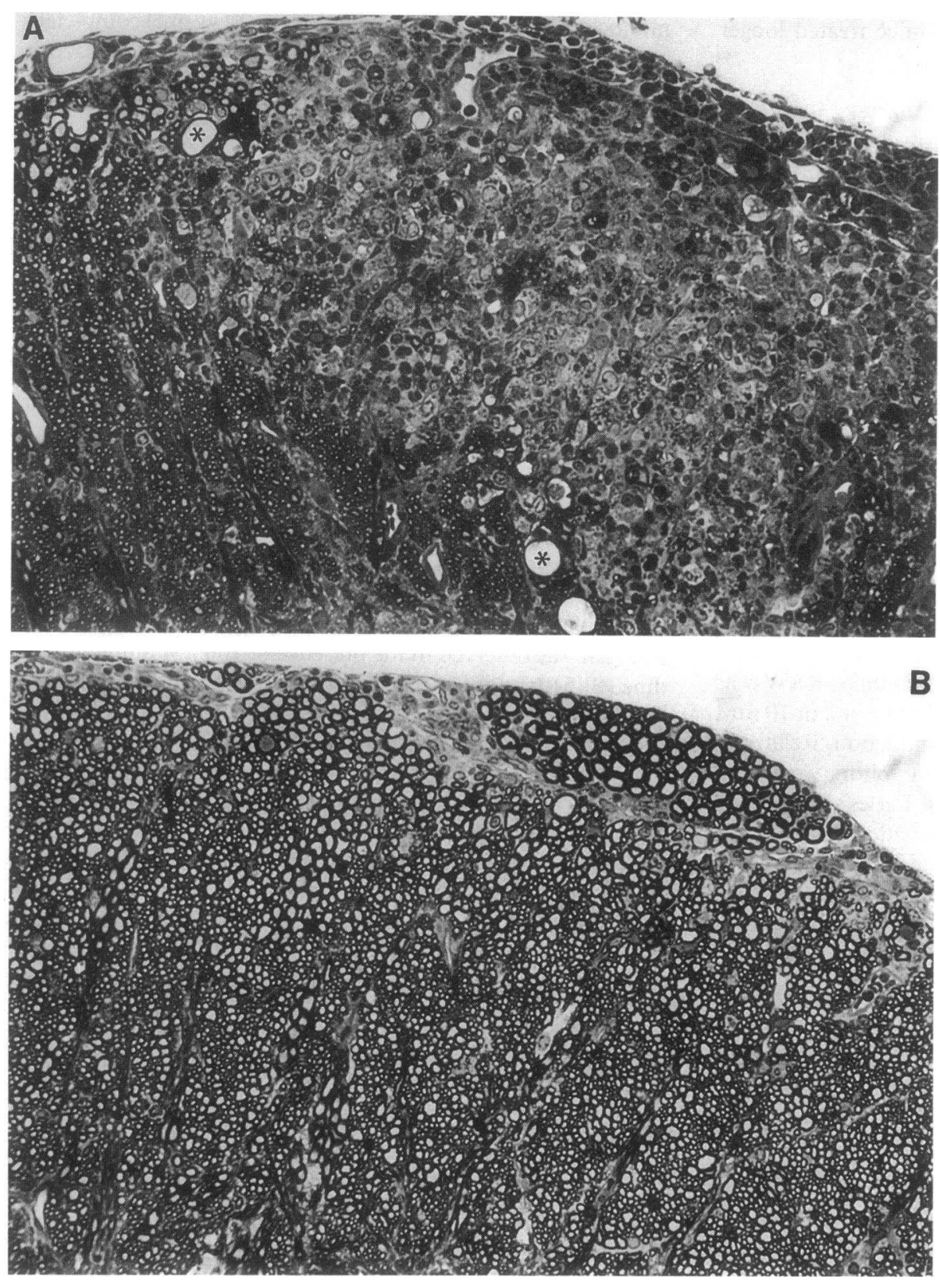

B

Figure 3. Representative sections from caudal spinal cords of placebo and aminoguanidine recipients. $(A)$ Section from the anterolateral white matter of the sacral spinal cord of a placebo-treated mouse with EAE, clinical grade 4, $11 \mathrm{~d}$ after cell transfer. Note the extensive demyelination, inflammatory infiltration and occasional axonal dropout $(*) .1-\mu \mathrm{m}$, plastic-embedded section, toluidine blue stain $(\times 230)$. At higher magnification, inflammatory cells were mainly mononuclear with occasional polymorphonuclear cells, and numerous healthy appearing demyelinated axons were apparent. $(B)$ A section from the anterior spinal cord of the same region of an aminoguanidine-treated mouse. Clinical grade$1.0,9 \mathrm{~d}$ after cell transfer. Note the minimal meningeal inflammatory cell infiltration and the healthy appearing myelin. An anterior root is at top right. $(\times 230)$.

aminoguanidine-treated donors was $2.2 \pm 1.6$ (range $=0-5$ ) and for the recipients of placebo-treated donors was $1.7 \pm 1.7$ ( range $=0-4.5$ ).

\section{Discussion}

The present study has shown that activated lymphocytes derived from MBP-immunized mice can induce NOS activity in a murine macrophage cell line and that an inhibitor of iNOS, aminoguanidine, inhibits the development of clinical and histopathologic manifestations of EAE. Induction of NOS activity in macrophages occurred equally well using conditioned medium taken from activated MBP-sensitized cell cultures and was inhibited by aminoguanidine and another recognized NOS inhibitor, L-NMA. Preliminary work indicated that IFN- $\gamma$ was necessary (although not necessarily sufficient) for the observed iNOS induction. Inhibition of EAE with aminoguanidine treatment occurred in a dose-related manner. At a dose of 400 $\mathrm{mg} / \mathrm{kg}$ per day, clinical disease was suppressed in terms of time to clinical onset and maximum clinical score. Neuropathologic features of EAE, especially inflammation and demyelination, were diminished. Aminoguanidine treatment of normal mice without EAE resulted in no clinical or pathologic abnormalities. Aminoguanidine did not appear to act by killing or inhibiting EAE-inducing $\mathrm{T}$ cells since antigen-specific proliferation and EAE transfer were unaffected by the presence of high concentrations of aminoguanidine. Furthermore, splenocytes from aminoguanidine-treated mice served as competent EAEinducer cells after activation with MBP. The present data would support a role for increased NO production at the effector stage of EAE.

Aminoguanidine exerts other well-characterized effects, in addition to its inhibition of NOS. Aminoguanidine is known to be a potent inhibitor of diamine oxidase (23) as well as hyper- 


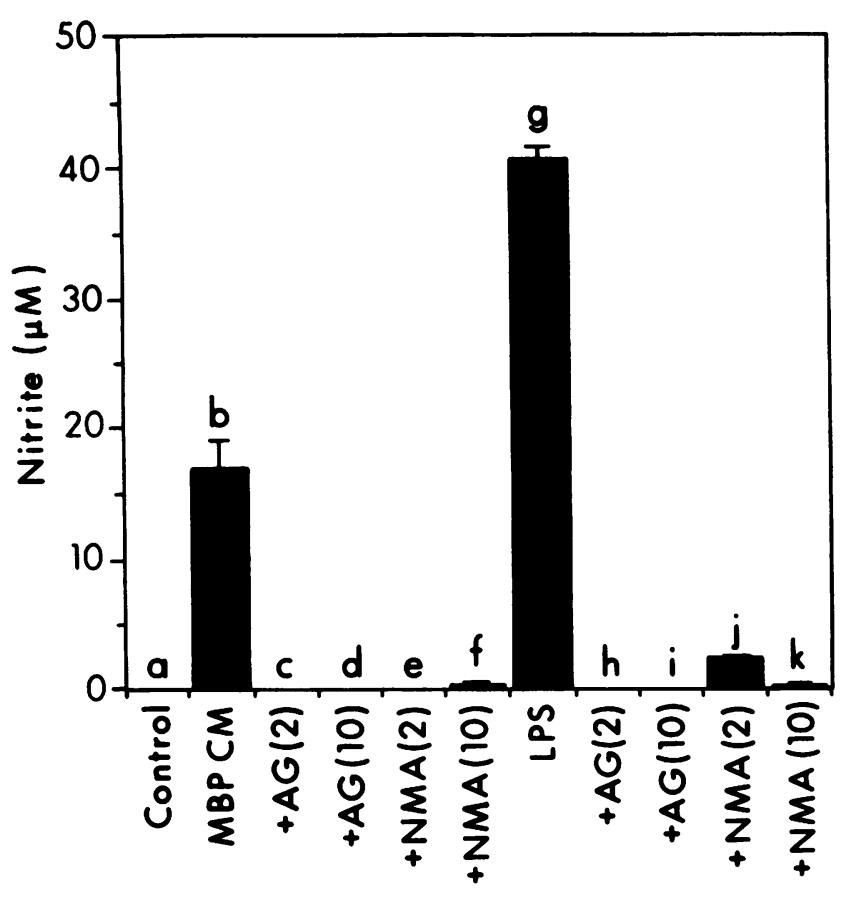

Figure 4. Induction of nitric oxide synthase activity in a murine macrophage cell line by conditioned medium from activated myelin basic protein-sensitized lymphocytes. Induction is suppressed by inhibitors of NOS. Nitrite levels were used as a measure of nitric oxide production by RAW 264.7 cells incubated for $17 \mathrm{~h}$ as follows: $(a)$ control (nothing added); $(b)$ supernatant fluid from myelin basic protein (MBP)-sensitized lymph node cells (LNC) capable of transferring EAE to naive recipients. $50 \%$ of the RAW cell medium was replaced with conditioned medium of LNC; $(c)$ supernatant fluid from MBP-sensitized LNC $+2 \mathrm{mM}$ aminoguanidine; $(d)$ supernatant fluid from MBP-sensitized LNC $+10 \mathrm{mM}$ aminoguanidine; $(e)$ supernatant fluid from MBP-sensitized LNC $+2 \mathrm{mM} N^{\mathrm{G}}$-monomethyl-L-arginine (L-NMA); $(f)$ supernatant fluid from MBP-sensitized LNC + 10 mM L-NMA; $(g) 10 \mu \mathrm{g} / \mathrm{ml} \mathrm{LPS;}(h)$ LPS $+2 \mathrm{mM}$ aminoguanidine; $(i)$ LPS $+10 \mathrm{mM}$ aminoguanidine; $(j)$ LPS +2 mM L-NMA; and $(k)$ LPS +10 mM L-NMA. Not shown: Supernates of unactivated LNC (LNC from naive, unimmunized SJL mice cultured with $50 \mu \mathrm{g} \mathrm{MBP} / \mathrm{ml}$ ) added to RAW cells led to no increased levels of nitrite $(<1 \mu \mathrm{M})$.

glycemia-induced advanced glycation end-product formation associated with diabetes (24). Aminoguanidine has been reported to inhibit aldose reductase activity (reduction of glucose to sorbitol, reference 25) and prevent apo B lysine modifications (aminoguanidine reacts with the reactive aldehyde products of lipid peroxidation) resulting in inhibition of macrophage uptake of oxidately damaged low density lipoprotein (26). Since diamine oxidase oxidatively deaminates putrescine, aminoguanidine may affect polyamine metabolism. None of these effects has a known role in the pathogenesis of EAE; thus it would appear unlikely that these effects played a role in its suppression of EAE.

Recent studies from this laboratory would support the notion that aminoguanidine inhibits EAE through its inhibition of NOS. Studies using electron paramagnetic resonance spectroscopy demonstrated the presence of nitrosyl-iron complexes in EAE-affected spinal cords concurrent with a diminution in iron-sulfur proteins (4). The toxicity of NO is known to be due in part to its affinity for, and subsequent destruction of, iron-sulfur proteins, which are crucial to the function of a number of enzymes, including enzymes of the Krebs cycle and electron transport chain $(27,28)$. Cytotoxic effects of increased NO production might destroy oligodendroglia, or impair the ability of myelin supporting cells to maintain and manufacture myelin. This notion is supported by a recent study implicating $\mathrm{NO}$ as an effector in microglial cell cytotoxicity toward oligodendroglia (29).

Activated macrophages, astrocytes, and other cell types can produce large quantities of $\mathrm{NO}$ via a calcium-independent inducible NOS-iNOS $(13,14,30)$. The inflammatory cells within EAE and MS lesions include large numbers of macrophages (31-34). Astroglial cell proliferation is another prominent feature of established and acute lesions $(31,35,36)$. Proinflammatory cytokines such as IFN- $\gamma$ and TNF $\alpha$ induce macrophage $(37,38)$ and astrocyte iNOS $(39)$ in vitro, apparently by transcriptional modulation $(40,41)$. These proinflammatory cytokines are known to be present in lesions of MS $(42,43)$ and appear to be important to the development of EAE $(44,45)$. Recent reports indicate NO also induces the production of TNF $(46,47)$. Although most studies of iNOS have used animal models, evidence for the existence of a human inducible isoform of NOS is accumulating (48-51). The present investigation, implicating the increased production of the free radical, NO, in the pathogenesis of murine EAE, provides a basis to suspect a role for NO in the human disease, MS.

\section{Acknowledgments}

This article is dedicated to the memory of Dr. Dale E. McFarlin. We thank Drs. Joseph R. Williamson, Harish Agrawal, Barbara Cannella, Mark G. Currie, Tien-Sung Tom Lin, and Cedric S. Raine for advice and discussion; Mr. Richard Keeling and Ms. Phyllis Hoffman for technical assistance; and Mr. Mike Province and Mr. Bradley Wilson of the Washington University Division of Biostatistics for assistance with statistical analyses.

This work was supported by grants from the National Multiple Sclerosis Society (JF-2059-A2 and PP-0291) and Monsanto Company to A. H. Cross.

\section{References}

1. Alvord, E. C., M. W. Kies, and A. J. Suckling. 1984. Experimental allergic encephalomyelitis: a useful model for multiple sclerosis. Prog. Clin. Biol. Res. 146:1-554.

2. Raine, C. S. 1984. Biology of disease: the analysis of autoimmune demyelination: its impact on multiple sclerosis. Lab. Invest. 50:608-635.

3. Zamvil, S. S., and L. Steinman. 1990. The T lymphocyte in experimental allergic encephalomyelitis. Annu. Rev. Immunol. 8:579-621.

4. Lin, R. F., T. T. Lin, R. G. Tilton, and A. H. Cross. 1993. Nitric oxide localized to spinal cords of mice with experimental allergic encephalomyelitis: an electron paramagnetic study. J. Exp. Med. 178:643-648.

5. MacMicking, J. D., D. O. Willenborg, M. K. Weidemann, K. A. Rockett, and W. B. Cowden. 1992. Elevated secretion of reactive nitrogen and oxygen intermediates by inflammatory leukocytes in hyperactive experimental autoimmune encephalomyelitis: enhancement by the soluble products of encephalitogenic T cells. J. Exp. Med. 176:303-307.

6. Koprowski, H., Y. M. Zheng, E. Heber-Katz, N. Fraser, L. Rorker, Z. F. Fu, C. Hanlon, and B. Dietzschold. 1993. In vivo expression of inducible nitric oxide synthase in experimentally induced neurologic disease. Proc. Natl. Acad. Sci. USA. 90:3024-3027.

7. Mulligan, M. S., J. M. Hevel, M. A. Marletta, and P. A. Ward. 1991. Tissue injury caused by deposition of immune complexes is L-arginine dependent. Proc. Natl. Acad. Sci. USA. 88:6338-6342.

8. Marletta, M. A. 1989. Nitric oxide: biosynthesis and biological significance. Trends Biochem. Sci. 14:188-192.

9. Granger, D. L., J. B. Hibbs, Jr., J. R. Perfect, and D. T. Durck. 1988. Specific amino acid (L-arginine) requirement for the microbiostatic activity of murine macrophages. J. Clin. Invest. 81:1129-1136. 
10. Stuehr, D. J., and M. A. Marletta. 1987. Induction of nitrite/nitrate synthesis in murine macrophages by BCG infection, lymphokines, or interferon- $\gamma . J$. Immunol. 139:518-525.

11. Hibbs, J. B., Jr., R. R. Taintor, Z. Vavrin, and E. M. Rachlin. 1988. Nitric oxide: a cytotoxic activated macrophage effector molecule. Biochem. Biophys. Res. Commun. 157:87-94.

12. Marletta, M. A., P. S. Yoon, R. Iyengar, C. D. Leaf, and J. S. Wishnok. 1988. Macrophage oxidation of L-arginine to nitrite and nitrate: nitric oxide is an intermediate. Biochemistry. 27:8706-8711.

13. Galea, E., D. L. Feinstein, and D. J. Reis. 1992. Induction of calcium-independent nitric oxide synthase activity in primary rat glial cultures. Proc. Natl. Acad. Sci. USA. 89:10945-10949.

14. Simmons, M. L., and S. Murphy. 1992. Induction of nitric oxide synthase in glial cells. J. Neurochem. 59:897-905.

15. Corbett, J. A., R. G. Tilton, K. Chang, K. S. Hasan, Y. Ido, J. L. Wang, M. A. Sweetland, J. R. Lancaster, Jr., J. R. Williamson, and M. L. McDaniel. 1992. Aminoguanidine inhibits nitric oxide formation and prevents diabetic vascular dysfunction. Diabetes. 41:552-556.

16. Misko, T. P., W. M. Moore, T. P. Kasten, G. A. Nickols, J. A. Corbett, R. G. Tilton, M. L. McDaniel, J. R. Williamson, and M. G. Currie. 1993. Selective inhibition of the inducible nitric oxide synthase by aminoguanidine. Eur. $J$. Pharmacol. 233:119-122.

17. Cross, A. H., R. McCarron, D. E. McFarlin, and C. S. Raine. 1987. Adoptively transferred acute and chronic relapsing autoimmune encephalomyelitis in the PL/J mouse and observations on altered pathology by intercurrent virus infection. Lab. Invest. 57:499-512.

18. Deibler, G. E., R. E. Martenson, and M. W. Kies. 1972. Large scale preparation of myelin basic protein from central nervous system tissue of several mammalian species. Prep. Biochem. 2:139-151.

19. Damiani, P., and G. Burini. 1986. Fluorometric determination of nitrite. Talanta. 33:649-652

20. Misko, T. P., R. J. Schilling, D. Salvemini, W. M. Moore, and M. G. Currie. 1993. A fluorometric assay for the measurement of nitrite in biological samples. Anal. Biochem. 214:11-16.

21. Moore, G. R. W., U. Traugott, M. Farooq, and C. S. Raine. 1984. Experimental autoimmune encephalomyelitis. Augmentation of demyelination by different myelin lipids. Lab. Invest. 51:416-424.

22. Cross, A. H., and C. S. Raine. 1990. Serial adoptive transfer of murine experimental allergic encephalomyelitis: successful transfer is dependent on active disease in the donor. $J$. Neuroimmunol. 28:27-37.

23. Lindell, S. E., K. Nilsson, B.-E. Roos, and H. Westling. 1960. The effect of enzyme inhibitors on histamine catabolism in man. Br. J. Pharmacol. 15:351355.

24. Brownlee, M., H. Vlassara, A. Kooney, P. Ulrich, and A. Cerami. 1986. Aminoguanidine prevents diabetes-induced arterial wall protein cross-linking. Science (Wash. DC). 240:1629-1632.

25. Kumari, K., S. Umar, V. Bansal, and M. K. Sahib. 1991. Monoaminoguanidine inhibits aldose reductase. Biochem. Pharmacol. 4:1527-1528.

26. Picard, S., S. Parthasarathy, J. Fruebis, and J. L. Witzum. 1992. Aminoguanidine inhibits oxidative modification of low density lipoprotein protein and the subsequent increase in uptake by macrophage scavenger receptors. Proc. Natl. Acad. Sci. USA. 89:6876-6880.

27. Henry, Y., C. Ducrocq, J.-C. Drapier, D. Servent, C. Pellat, and A. Guissani. 1991. Nitric oxide, a biologic effector. Electron paramagnetic resonance detection of nitrosyl-iron-protein complexes in whole cells. Eur. Biophys. J. 20:1 15.

28. Drapier, J.-C., and J. B. Hibbs, Jr. 1988. Differentiation of murine macrophages to express nonspecific cytotoxicity for tumor cells results in L-arginine-dependent inhibition of mitochondrial ironsulfur enzymes in the macrophage effector cell. J. Immunol. 140:2829-2838.

29. Merrill, J. E., L. J. Ignarro, M. P. Sherman, J. Melinek, and T. E. Lane. 1993. Microglial cell cytotoxicity of oligodendrocytes is mediated through nitric oxide. J. Immunol. 151:2132-2141.

30. Stuehr, D. J., H. J. Cho, N. S. Kwon, M. F. Weise, and C. F. Nathan. 1991 Purification and characterization of the cytokine-induced macrophage nitric oxide synthase. An FAD- and FMN-containing flavoprotein. Proc. Natl. Acad. Sci. USA. 88:7773-7777.
31. Prineas, J. W. 1985. The neuropathology of multiple sclerosis. In Handbook of Clinical Neurology. Vol. 3:47. Demyelinating Disease. J. C. Koetsier, editor. Elsevier Science Publishers B.V., Amsterdam. 213-257.

32. Raine, C. S., F. Mokhtarian, and D. W. McFarlin. 1984. Adoptively transferred chronic relapsing experimental autoimmune encephalomyelitis in the mouse. Neuropathologic analysis. Lab. Invest. 51:534-546.

33. Traugott, U., D. E. McFarlin, and C. S. Raine. 1986. Immunopathology of the lesion in chronic relapsing EAE in the mouse. Cell. Immunol. 99:395-410.

34. Hauser, S., A. K. Bhan, F. Gilles, M. Kemp, C. Kerr, and H. L. Weiner. 1986. Immunohistochemical analysis of the cellular infiltrate in multiple sclerosis lesions. Ann. Neurol. 19:578-587.

35. Prineas, J. W., and C. S. Raine. 1976. Electron microscopy and immunoperoxidase studies of early multiple sclerosis lesions. Neurology 26(Suppl. 2):2932.

36. Dawson, J. W. 1916. The histology of disseminated sclerosis. Trans. $R$ Soc. Edinb. 50:517-740.

37. Ding, A. H., C. F. Nathan, and D. J. Stuehr. 1988. Release of reactive nitrogen intermediates and reactive oxygen intermediates from mouse peritoneal macrophages. Comparison of activating cytokines. J. Immunol. 141:2407-2412.

38. Drapier, J.-C., J. Wietzerbin, and J. B. Hibbs, Jr. 1988. Interferon- $\gamma$ and tumor necrosis factor induce the L-arginine dependent cytotoxic effector mechanism in murine macrophages. Eur. J. Immunol. 18:1587-1592.

39. Lee, S. C., C. F. Brosnan, W. Liu, and D. W. Dickson. 1993. Activation of nitric oxide synthase pathway in human fetal astrocytes by IL-1 $\beta$ and IFN- $\gamma . J$. Neuroimmunol. 46:19-25.

40. Xie, Q.-W., H. J. Cho, J. Calaycay, R. A. Mumford, K. M. Swiderek, T. D. Lee, A. Ding, T. Troso, and C. Nathan. 1992. Cloning and characterization of inducible nitric oxide synthase from mouse macrophages. Science (Wash. DC). 256:225-228.

41. Lyons, C. R., G. J. Orlogg, and J. M. Cunningham. 1992. Molecular cloning and functional expression of an inducible nitric oxide synthase from a murine macrophage cell line. J. Biol. Chem. 267:6370-6374.

42. Traugott, U., and P. Lebon. 1988. Multiple sclerosis: involvement of interferons in lesion pathogenesis. Ann. Neurol. 24:243-251.

43. Hofman, F. M., D. R. Hinton, K. Johnson, and J. E. Merrill. 1989. Tumor necrosis factor identified in multiple sclerosis brain. J. Exp. Med. 170:607-612.

44. Ruddle, N. H., C. M. Bergman, and K. M. McGrath. 1990. An antibody to lymphotoxin and tumor necrosis factor prevents transfer of experimental allergic encephalomyelitis. J. Exp. Med. 172:1193-1200.

45. Selmaj, K., C. S. Raine, and A. H. Cross. 1991. Anti-cytokine therapy abrogates autoimmune demyelination. Ann. Neurol. 30:694-700.

46. Magrinat, G. C., S. N. Mason, P. J. Sahmi, and J. B. Weinberg. 1992. Nitric oxide modulation of human leukemia cell differentiation: induction of tumor necrosis factor mRNA by nitric oxide. Clin. Res. 40:297. (Abstr.)

47. Lander, H. M., P. Sehajpal, D. M. Levine, and A. Novogrodsky. 1993. Activation of human peripheral blood mononuclear cells by nitric oxide-generating compounds. J. Immunol. 150:1509-1516.

48. Denis, M. 1991. Tumor necrosis factor and granulocyte macrophage-colony stimulating factor stimulate human macrophages to restrict growth of virulent $M y$ cobacterium avium and to kill avirulent $M$. avium: killing effector mechanism depends on the generation of reactive nitrogen intermediates. J. Leuk. Biol. 49:380-387.

49. Jacob, T. D., M. K. Morrell, S. Munzi, J. B. Ochoa, V. Verdile, A. O Udekwu, S. A. Berceli, R. L. Simmons, and A. B. Peitzman. 1992. Elevated levels of nitrates in human joint fluid: a role for nitric oxide as a peripheral mediator of inflammation. Abstract in Nitric Oxide: Implications for Drug Research. Philadelphia, PA, June 1-2, 1992.

50. Nussler, A. K., M. DiSilvio, T. R. Billiar, R. A. Hoffman, D. A. Geller, R. Selby, J. Madariaga, and R. L. Simmons. 1992. Stimulation of the nitric oxide synthase pathway in human hepatocytes by cytokines and endotoxin. $J$. Exp. Med. 176:261-264.

51. Geller, D. A., C. J. Lowenstein, R. A. Shapiro, A. K. Nussler, M. DiSilvio, S. C. Wang, D. K. Nakayama, R. L. Simmons, S. H. Snyder, and T. R. Billiar. 1993. Molecular cloning and expression of inducible nitric oxide synthase from human hepatocytes. Proc. Natl. Acad. Sci. USA. 90:3491-3495. 